\title{
The Influence of the Adiwiyata Program on the Curriculum Policy in Basic Education
}

\author{
Ahwy Oktradiksa ${ }^{1}$, Minzani Aufa ${ }^{2}$, Muis $\operatorname{Sad~Iman}^{3}$, C. Asri Budiningsih ${ }^{4}$ \\ \{minzaniaufa@ummgl.ac.id² \\ Teacher Education of Madrasah Ibtidaiyah, Muhammadiyah University of Magelang 1,2,3 \\ Yogyakarta State University ${ }^{4}$
}

\begin{abstract}
The purpose of this study was to determine the effect of curriculum constructs on the Adiwiyata program at the elementary level in order to increase students' knowledge and understanding of environmental themes in the 2013 curriculum, as well as environmentally friendly school services provided to Adiwiyata schools. The constructive theory paradigm is comprised of qualitative and quantitative approaches utilizing descriptive natural methods. This study surveyed 60 respondents with only a high school education. The results indicated a positive correlation between the systematic validity test and the reliable test and normality test, followed by the one-sample Kolmogorov-Smirnov test to determine the significance value. As a result, the Adiwiyata Program and Adiwiyata curriculum policies contribute to the development of sustainable education, particularly at the elementary level.
\end{abstract}

Keywords: Adiwiyata, curriculum policy, basic education

\section{Introduction}

The sustainable development program [1] has become a shared commitment and responsibility for the world community to save the earth from damage and destruction caused by development that does not pay attention to environmental sustainability[2][3]. One way to increase capacity in realizing this development is to support environmental protection programs to understand students through the world of education [4][5]. The Adiwiyata program is governed by Minister of Environment Regulation Number 5 of 2013, which establishes the following: 1) Adiwiyata schools are those that care about the environment and have an environmental culture; 2) the Adiwiyata program is one that works to establish such a school through the implementation of three educational, participatory, and sustainable principles. The Adiwiyata program participants must be followed by education, one of which is the primary education level; elementary school (SD) and madrasah Ibtaiyah (MI)[6]. However, schools and madrasahs have not implemented the basic principles of the Adiwiyata program both in the learning curriculum process and in student and teacher activities outside the learning process [4],[7]. This can be seen from the following problems: 1) the curriculum applied in MI / SD on the subject matter with the theme of the environment (LH) has not fully supported the vision, the mandatory mission to implement Adiwiyata school; 2) lack of availability of environmentally friendly supporting infrastructure, 3) lack of awareness of school members (students, teachers, employees, alumni, stakeholders, madrasah committees) in carrying out planned environmental protection and management activities for school residents. The research 
objectives are: 1) increasing knowledge and understanding of thematic/environmental themes in the 2013 curriculum content; 2) improving environmentally-friendly school services; 3) increasing good cooperation to realize schools towards Adiwiyata jointly.

\section{Literature Review}

Adiwiyata is another name for eco-school, but it was more popular in Indonesia as Adiwiyata. Adiwiyata is an endeavor to create a good and ideal program or forum for the purpose of acquiring knowledge and various standards and ethics that can serve as a foundation for human beings in their pursuit of a prosperous life consistent with the ideals of sustainable development. The Adiwiyata program's objective is to develop school members who are responsible for environmental protection and management through sound school governance in order to promote sustainable development [8]. The Adiwiyata program's fundamental principles. The Adiwiyata program is based on two fundamental principles: a) Participatory: The school community is involved in all aspects of school management, including planning, implementation, and evaluation, according to assigned responsibilities and roles; and b) Continuous: All activities must be planned and executed in a systematic and comprehensive manner. The Ministry of Environment regulates the Adiwiyata program, which defines Adiwiyata schools as those that care about the environment and have an environmental culture, while the Adiwiyata program organizers range from Elementary School / Madrasah Ibtidiayah (SD/MI) to Senior High School / Madrasah Aliyah (SMA/MA) as public or private schools [6][9][10].

Environmental education is a description of students' state of knowledge and attitudes to appreciate and understand the word ecosystem concept. When viewed from the cognitive aspect, environmental education means developing the understanding of the biosphere, namely the layer of the earth as the habitable space for humans and other living things. Lack of human knowledge about the concept of ecology will affect human behavior errors in the environment [11][12]. In 2006, the Ministry of Education and Culture in collaboration with the Minister of Environment established environment-based schools in Indonesia. In Indonesia, the eco-school program is called Adiwiyata, and it aims to develop school members who are responsible for protecting and preserving the environment through schools that promote sustainable development [13].

\section{Method}

This study uses a constructive paradigm with a qualitative approach, [14][15] descriptive narrative method of data collection techniques with literacy studies, interviews, and questionnaire distribution with the classification of 60 respondents head of MI / SD in Magelang Regency as presented in Table 1. 
Table 1. The Numbers of Respondent Based on Status and Origin of School

\begin{tabular}{llll}
\hline \multirow{2}{*}{ School } & \multicolumn{2}{c}{ Status } \\
\cline { 2 - 4 } & \multicolumn{2}{c}{ Principal/ Vice Principal } & \% \\
\hline Private of MI & 43 & 72 & \\
State of MI & 6 & 2 & \\
Private of Elementary school & 1 & 17 & \\
State of Elementary school & 10 & 100 \\
Total & 60 &
\end{tabular}

\section{Results and Discussions}

The purpose of this study was to determine the effect of curriculum construct [16] on the Adiwiyata level basic education program to increase knowledge and understanding of environmental themes in the national curriculum [17] in 2013, environmentally friendly school services to Adiwiyata schools. There are two purposes for the Adiwiyata school; 1) adopting an environmental management system as part of educational excellence, 2) changing how students perceive and interact with nature as a form of tolerance [18][19]. This research focuses on two variables: the dependent variable Adiwiyata program and the Adiwiyata curriculum policy's independent variable.

\subsection{Validity test}

Table 2. The result of validities test-X: Adiwiyata program

\begin{tabular}{|c|c|c|c|c|c|c|c|c|}
\hline & & $\begin{array}{c}\text { Concept } \\
\text { Adiwiyata } \\
\text { program }\end{array}$ & $\begin{array}{c}\text { Guidance } \\
\text { program }\end{array}$ & $\begin{array}{l}\text { Adiwiyata } \\
\text { program }\end{array}$ & $\begin{array}{c}\text { Learning } \\
\text { output } \\
\text { program }\end{array}$ & $\begin{array}{c}\text { Vision, } \\
\text { mission } \\
\text { school }\end{array}$ & $\begin{array}{l}\text { Budget } \\
\text { program }\end{array}$ & $\begin{array}{c}\text { Adiwiyata } \\
\text { program }\end{array}$ \\
\hline \multirow[t]{3}{*}{$\mathrm{X} 1$} & $\begin{array}{l}\text { Pearson } \\
\text { Correlation }\end{array}$ & 1 & 0.127 & 0.235 & 0.185 & 0.224 & -.041 & $0.471^{* *}$ \\
\hline & Sig. (2-tailed) & & 0.332 & 0.071 & 0.157 & 0.085 & 0.755 & 0.000 \\
\hline & $\mathrm{N}$ & 60 & 60 & 60 & 60 & 60 & 60 & 60 \\
\hline \multirow[t]{3}{*}{$\mathrm{X} 2$} & $\begin{array}{l}\text { Pearson } \\
\text { Correlation }\end{array}$ & 0.127 & 1 & 0.174 & 0.165 & 0.100 & 0.220 & $0.526^{* *}$ \\
\hline & Sig. (2-tailed) & 0.332 & & 0.182 & 0.207 & 0.447 & 0.091 & 0.000 \\
\hline & $\mathrm{N}$ & 60 & 60 & 60 & 60 & 60 & 60 & 60 \\
\hline \multirow[t]{3}{*}{$\mathrm{X} 3$} & $\begin{array}{l}\text { Pearson } \\
\text { Correlation }\end{array}$ & 0.235 & 0.174 & 1 & $0.718^{* *}$ & $0.256^{*}$ & 0.187 & $0.715^{* *}$ \\
\hline & Sig. (2-tailed) & 0.071 & 0.182 & & 0.000 & 0.049 & 0.151 & 0.000 \\
\hline & $\mathrm{N}$ & 60 & 60 & 60 & 60 & 60 & 60 & 60 \\
\hline \multirow[t]{3}{*}{$\overline{\mathrm{X} 4}$} & $\begin{array}{l}\text { Pearson } \\
\text { Correlation }\end{array}$ & 0.185 & 0.165 & $0.718^{* *}$ & 1 & $0.303^{*}$ & $0.444^{* *}$ & $0.769^{* *}$ \\
\hline & Sig. (2-tailed) & 0.157 & 0.207 & 0.000 & & 0.019 & 0.000 & 0.000 \\
\hline & $\mathrm{N}$ & 60 & 60 & 60 & 60 & 60 & 60 & 60 \\
\hline
\end{tabular}




\begin{tabular}{lllllll|l|l}
\hline X5 & $\begin{array}{l}\text { Pearson } \\
\text { Correlation }\end{array}$ & 0.224 & 0.100 & $0.256^{*}$ & $0.303^{*}$ & 1 & $0.371^{* *}$ & $0.567^{* *}$ \\
& $\begin{array}{l}\text { Sig. (2-tailed) } \\
\text { N }\end{array}$ & 0.085 & 0.447 & 0.049 & 0.019 & & 0.004 & 0.000 \\
& 60 & 60 & 60 & 60 & 60 & 60 & 60 \\
\hline X6 & $\begin{array}{l}\text { Pearson } \\
\text { Correlation }\end{array}$ & -.041 & 0.220 & 0.187 & $0.444^{* *}$ & $0.371^{* *}$ & 1 & $0.595^{* *}$ \\
& Sig. (2-tailed) & 0.755 & 0.091 & 0.151 & 0.000 & 0.004 & & 0.000 \\
& N & 60 & 60 & 60 & 60 & 60 & 60 & 60 \\
\hline X & $\begin{array}{l}\text { Pearson } \\
\text { Correlation }\end{array}$ & $0.471^{* *}$ & $0.526^{* *}$ & $0.715^{* *}$ & $0.769^{* *}$ & $0.567^{* *}$ & $0.595^{* *}$ & 1 \\
& Sig. (2-tailed) & 0.000 & 0.000 & 0.000 & 0.000 & 0.000 & 0.000 & \\
& N & 60 & 60 & 60 & 60 & 60 & 60 & 60 \\
\hline
\end{tabular}

**. Correlation is statistically significant at the 0.01 (2-tailed) level.

*. Correlation is statistically significant at the 0.05 level (2-tailed).

Table 3. The result of validities test-Y: Adiwiyata curriculum policy

\begin{tabular}{|c|c|c|c|c|c|c|c|c|}
\hline & & $\begin{array}{c}\text { Adiwiyata } \\
\text { material } \\
\text { program }\end{array}$ & $\begin{array}{c}\text { Learning } \\
\text { act in } \\
\text { teaching } \\
\text { program }\end{array}$ & $\begin{array}{l}\text { Learning } \\
\text { product } \\
\text { program }\end{array}$ & $\begin{array}{l}\text { Learning } \\
\text { media } \\
\text { program }\end{array}$ & $\begin{array}{c}\text { Learning } \\
\text { curricular } \\
\text { program }\end{array}$ & $\begin{array}{c}\text { Learning } \\
\text { integrated } \\
\text { act } \\
\text { program }\end{array}$ & $\begin{array}{c}\text { Adiwiyata } \\
\text { curriculum } \\
\text { policies }\end{array}$ \\
\hline \multirow[t]{3}{*}{$\overline{Y 1}$} & Pearson Correlation & & $0.401^{* *}$ & $0.389^{* *}$ & $0.447^{* *}$ & $0.450^{* *}$ & $0.411^{* *}$ & $0.726^{* *}$ \\
\hline & Sig. (2-tailed) & & .001 & .002 & .000 & .000 & .001 & .000 \\
\hline & $\mathrm{N}$ & 60 & 60 & 60 & 60 & 60 & 60 & 60 \\
\hline \multirow[t]{3}{*}{$\mathrm{Y} 2$} & Pearson Correlation & $0.401^{* *}$ & 1 & $0.334^{* *}$ & $0.406^{* *}$ & $0.267^{*}$ & $0.342^{* *}$ & $0.646^{* *}$ \\
\hline & Sig. (2-tailed) & 0.001 & & 0.009 & 0.001 & 0.039 & 0.007 & 0.000 \\
\hline & $\mathrm{N}$ & 60 & 60 & 60 & 60 & 60 & 60 & 60 \\
\hline \multirow[t]{3}{*}{$\overline{\mathrm{Y} 3}$} & Pearson Correlation & $0.389^{* *}$ & $0.334^{* *}$ & 1 & $0.550^{* *}$ & $0.448^{* *}$ & $0.585^{* *}$ & $0.758^{* *}$ \\
\hline & Sig. (2-tailed) & 0.002 & 0.009 & & 0.000 & 0.000 & 0.000 & 0.000 \\
\hline & $\mathrm{N}$ & 60 & 60 & 60 & 60 & 60 & 60 & 60 \\
\hline \multirow[t]{3}{*}{$\overline{\mathrm{Y} 4}$} & Pearson Correlation & $0.447^{* *}$ & $.406^{* *}$ & $0.550^{* *}$ & 1 & $0.526^{* *}$ & $0.379^{* *}$ & $0.754^{* *}$ \\
\hline & Sig. (2-tailed) & 0.000 & 0.001 & 0.000 & & 0.000 & 0.003 & 0.000 \\
\hline & $\mathrm{N}$ & 60 & 60 & 60 & 60 & 60 & 60 & 60 \\
\hline \multirow[t]{3}{*}{$\overline{Y 5}$} & Pearson Correlation & $0.450^{* *}$ & $0.267^{*}$ & $0.448^{* *}$ & $0.526^{* *}$ & 1 & $0.387^{* *}$ & $0.707^{* *}$ \\
\hline & Sig. (2-tailed) & 0.000 & 0.039 & 0.000 & 0.000 & & 0.002 & 0.000 \\
\hline & $\mathrm{N}$ & 60 & 60 & 60 & 60 & 60 & 60 & 60 \\
\hline \multirow[t]{3}{*}{ Y6 } & Pearson Correlation & $0.411^{* *}$ & $0.342^{* *}$ & $0.585^{* *}$ & $0.379^{* *}$ & $0.387^{* *}$ & 1 & $0.726^{* *}$ \\
\hline & Sig. (2-tailed) & 0.001 & 0.007 & 0.000 & 0.003 & 0.002 & & 0.000 \\
\hline & $\mathrm{N}$ & 60 & 60 & 60 & 60 & 60 & 60 & 60 \\
\hline \multirow[t]{3}{*}{$\overline{\mathrm{Y}}$} & Pearson Correlation & $0.726^{* *}$ & $0.646^{* *}$ & $0.758^{* *}$ & $0.754^{* *}$ & $0.707^{* *}$ & $0.726^{* *}$ & 1 \\
\hline & Sig. (2-tailed) & 0.000 & 0.000 & 0.000 & 0.000 & 0.000 & 0.000 & \\
\hline & $\mathrm{N}$ & 60 & 60 & 60 & 60 & 60 & 60 & 60 \\
\hline
\end{tabular}

**. Correlation is statistically significant at the 0.01 (2-tailed) level.

*. Correlation is statistically significant at the 0.05 level (2-tailed). 
The observations on the r-table obtained the value of the sample $(\mathrm{N})=60$ of 0.2452 . Referring to the results of the validity test results, it is produced that all instruments starting from variable X (Adiwiyata program) consisting of X1- X6 all produce (r-count) $>$ than (r-table) of 0.2542 besides that based on the test results validity resulted that all instruments starting from variable Y (Adiwiyata curriculum policy) consisting of Y1-Y6 all produce (r-count) $>$ than ( $\mathrm{r}$ table) so it can be concluded that all instruments in this study can be said to be valid.

\subsection{Reliability test}

Table 4 and Table 5 show the reliability test of variable $\mathrm{X}$ dan $\mathrm{Y}$

Table 4. The result of variabel-X: Adiwiyata program

Reliability Statistics

\begin{tabular}{ll}
\hline Cronbach's Alpha & N of Items \\
\hline 0.649 & 6 \\
\hline
\end{tabular}

Table 5. The result of variable-Y: Adiwiyata curriculum policy

\begin{tabular}{ll}
\multicolumn{2}{c}{ Reliability Statistics } \\
\hline Cronbach's Alpha & N of Items \\
\hline 0.811 & 6 \\
\hline
\end{tabular}

From the results of the reliability test, all values from the $\mathrm{X}$ and $\mathrm{Y}$ variables resulted in values $>$ alpha Cronbach 0.6. It can be concluded that all the instruments in this study are reliable.

\subsection{Normality test}

Table 6 show the normality test that the significance value for the normality test is $0.015>0.05$, it can be concluded that the residual value is normally distributed.

Table 6. One-Sample Kolmogorov-Smirnov Test

\begin{tabular}{lll}
\hline $\mathrm{N}$ & & Unstandardized Residual \\
\hline Normal Parameters ${ }^{\mathrm{a}, \mathrm{b}}$ & Mean & 60 \\
\cline { 2 - 3 } & Std. Deviation & .0000000 \\
\hline Most Extreme Differences & Absolute & 1.97021400 \\
\cline { 2 - 3 } & Positive & 0.129 \\
\cline { 2 - 3 } & Negative & 0.129 \\
\hline Test Statistic & & -.083 \\
\hline Asymp. Sig. (2-tailed) & & .0129 \\
\hline
\end{tabular}

a. Test distribution is Normal.

b. Calculated from data.

c. Lilliefors Significance Correction. 


\subsection{Simple linear regression test}

Table 7 explains the correlation/relationship coefficient $(\mathrm{R})$, which is equal to 0.437. The coefficient (R-Square) is estimated to be 0.191 from this output, implying that the effect of the independent variable (adiwiyata program) on the dependent variable (adiwiyata curriculum policy) is 19.1 percent.

Table 7. Model Summary

\begin{tabular}{lll|l|l}
\hline Model & R & R Square & Adjusted R Square & $\begin{array}{c}\text { Std. Error of the } \\
\text { Estimate }\end{array}$ \\
\cline { 1 - 2 } 1 & $0.437^{\mathrm{a}}$ & 0.191 & 0.177 & 1.98713 \\
\hline
\end{tabular}

a. Predictors: (Constant), Eco-school program

b. Dependent Variable: Eco-school curriculum policies

Table 8. ANOVA

\begin{tabular}{|c|c|c|c|c|c|c|}
\hline Model & & Sum of Squares & df & Mean Square & $\mathbf{F}$ & Sig. \\
\hline \multirow[t]{3}{*}{1} & Regression & 53.960 & 1 & 53.960 & 13.665 & $0.000^{\mathrm{b}}$ \\
\hline & Residual & 229.023 & 58 & 3.949 & & \\
\hline & Total & 282.983 & 59 & & & \\
\hline
\end{tabular}

a. Dependent Variable: Eco-school curriculum policies

b. Predictors: (Constant), Eco-school program

This output indicates that the F value was 13.665 with a 0.0000 .05 significance level. It is possible to assert that the Adiwiyata program variable (X) has an effect on the Adiwiyata curriculum policy variable (Y).

Table 9. Coefficientsa

\begin{tabular}{|c|c|c|c|c|c|c|}
\hline \multirow[b]{2}{*}{ Model } & & \multicolumn{2}{|c|}{ Unstandardized Coefficients } & \multirow{2}{*}{$\begin{array}{l}\text { Standardized } \\
\text { Coefficients } \\
\text { Beta }\end{array}$} & \multirow[b]{2}{*}{$\mathrm{t}$} & \multirow[b]{2}{*}{ Sig. } \\
\hline & & $\mathrm{B}$ & Std. Error & & & \\
\hline \multirow[t]{2}{*}{1} & (Constant) & 15.405 & 2.873 & & 5.362 & 0.000 \\
\hline & Program Adiwiyata & 0.421 & 0.114 & 0.437 & 3.697 & 0.000 \\
\hline
\end{tabular}

a. Dependent Variable: Eco-school curriculum policies

It is known that the constant value) is 15.405 , and the Adiwiyata program value (w / regression coefficient) is 0.421 , which allows for the following formulation of the regression equation:

$$
\begin{gathered}
\mathrm{Y}=\mathrm{a}+\mathrm{bx} \\
\mathrm{Y}=15,405+0,421 \mathrm{x}
\end{gathered}
$$

The equation represents decoded data 
a. The constant value of 15,405 indicates that the consistent value of the curriculum policy variable is 15,405 as well.

b. The X regression coefficient of 0.421 indicates that for every $1 \%$ increase in the value of the Adiwiyata program, the curriculum policy's value increases by 0.421 . Because the regression coefficient is positive, the direction of variable $\mathrm{X}$ 's influence on variable $\mathrm{Y}$ is positive

A simple linear regression test can be used to derive a decision from this data:

a. Given the significance value of 0.0000 .05 , the coefficient table indicates that the Adiwiyata Program variable (X) has an effect on curriculum policy (Y)

b. Given that the $t$ value is $3.697>t$ table 0.2144 , it can be concluded that the Adiwiyata program variable $(\mathrm{X})$ has an effect on the Adiwiyata curriculum policy.

c. The Adiwiyata program and Adiwiyata curriculum policies are very supportive of the development of sustainable education, especially at the basic education level were educating students from an early age to provide awareness of human dependence on the natural environment as well as social beings so that they can participate, be active, and have knowledge about equality, justice with nature [20],[21].

\subsection{Simple linear regression test curve}

The following Figure 1 is the result of a simple linear regression test which shows a positive point of influence:

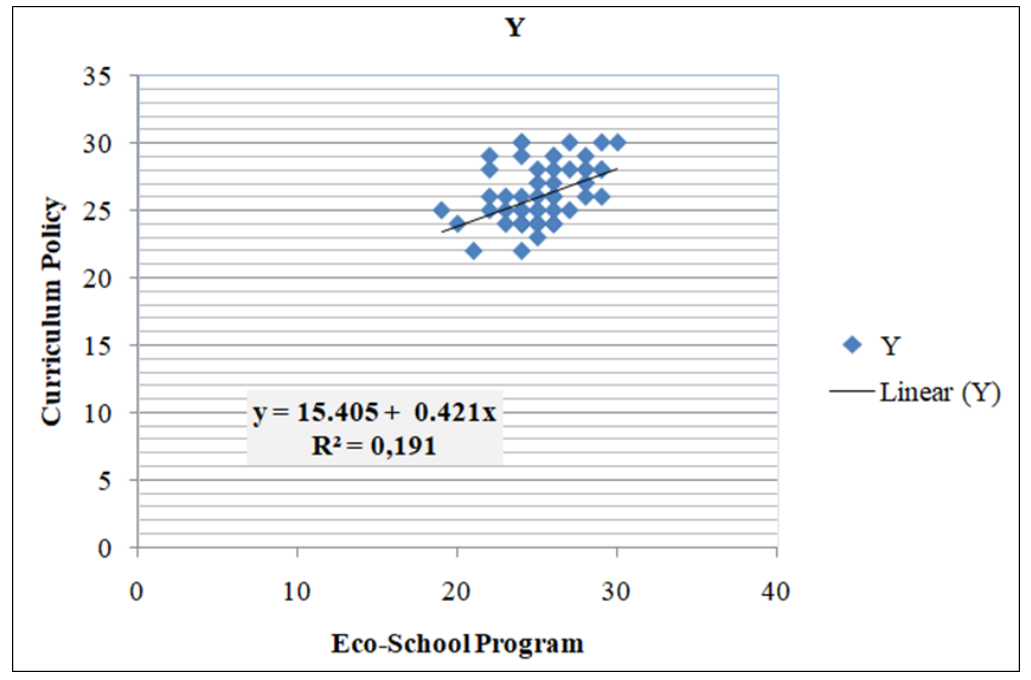

Fig.1. Simple linear regression test curve

The curve above explains the consistent value of 15.405 , the curriculum policy variable's constant value. The regression coefficient of $\mathrm{X}$ is 0.421 , indicating that a $1 \%$ increase in the value of the Adiwiyata program indicates that it is positive, indicating the direction of variable $\mathrm{X}$ 's influence on Y. Then, in linear regression, the points on the curve indicate parallelism. 


\section{Conclusion}

The discussion concludes that there is a positive relationship between the Adiwiyata program and the Adiwiyata curriculum policy in terms of providing an understanding of the content contained at the elementary education level, as evidenced by the significant effect of the coefficient table obtained by a significance value of 0.0000 .05 and the $t$ value of $3.697>t$ table 0.2144 . In this case, the Adiwiyata program is extremely supportive of curriculum policies.

\section{Acknowledgement}

These authors would like to thank LPPM, Muhamamdiyah Magelang University, for facilitating the Borobudur International Symposium and Madrasah Ibtidaiyah Teacher Education Study Program for sponsoring the completion of this research article.

\section{References}

[1] M. Desfandi, E. Maryani, and Disman, "Building Ecoliteracy Through Adiwiyata Program (Study at Adiwiyata School in Banda Aceh)," Indones. J. Geogr., vol. 49, no. 1, pp. 51-56, 2017, doi: 10.22146/ijg.11230.

[2] D. P. Veronese and L. A. W. Kensler, "School leaders, sustainability, and green school practices: An elicitation study using the Theory of Planned Behavior," J. Sustain. Educ., vol. 4, no. January, 2013, [Online]. Available: http://www.susted.org/.

[3] L. D.- EDUTECH, "Pendidikan Lingkungan Hidup Mengenai Pengelolaan Dan Pengolahan Sampah: Perspektif Peserta Didik," Ejournal.Upi.Edu, vol. 19, no. 2, pp. 150-172, 2020, [Online]. Available: https://ejournal.upi.edu/index.php/edutech/article/view/24624.

[4] L. Somwaru, "The Green School: a sustainable approach towards environmental education: Case study,” Brazilian J. Sci. Technol., vol. 3, no. 1, 2016, doi: 10.1186/s40552-016-0023-6.

[5] A. Suryani et al., "Education for Environmental Sustainability: A Green School Development," IPTEK J. Proc. Ser., vol., no. 6, p. 65, 2019, doi: 10.12962/j23546026.y2019i6.6347.

[6] P. A. Permen LH No 5 Tahun 2013, "Permen LH No. 5 Tahun 2013, Penyelenggaraan Adiwiyata," E-Print Lampiran Permen LH No. 5 Tahun 2013, vol. 9, no. 3, pp. 399-401, 1986, doi: 10.1017/CBO9781107415324.004.

[7] M. del C. Conde and J. Samuel Sánchez, "The school curriculum and environmental education: A school environmental audit experience,” Int. J. Environ. Sci. Educ., vol. 5, no. 4, pp. 477-494, 2010.

[8] \& S. Assad, I., Muhammad, H., "Panduan Adiwiyata Sekolah Peduli dan Berbudaya Lingkungan," pp. 1-88, 2011.

[9] I. Al-harthy, "The Role of Eco-School Program (Adiwiyata) towards Environmental Literacy of High School Students," Eur. J. Educ. Res., vol. 8, no. 4, pp. 91-101, 2019, doi: 10.12973/eu-jer.9.3.1089.

[10] D. Krnel and S. Naglic, "Environmental literacy comparison between eco-schools and ordinary schools in Slovenia," Sci. Educ. Int., vol. 20, no. 1, pp. 5-24, 2009.

[11] A. J. Goldbloom, Environmental science research. Springer US, 1980.

[12] T. Yusnidar, D. Liesnoor, and E. Banowati, "Peran Serta Warga Sekolah Dalam Mewujudkan Program Adiwiyata Di Smp Wilayah Semarang Barat," JESS (Journal Educ. Soc. Stud., vol. 4, no. 1, pp. 1-7, 2015, doi: 10.15294/jess.v4i1.6865.

[13] M. Desfandi, E. Maryani, and D. Disman, "The Role of School Principal Leadership in Implementation of Eco School Program as the Effort to Support Sustainable Development," vol. 14, pp. 197-200, 2016, doi: 10.2991/icemal-16.2016.40. 
[14] J. . Creswell, Research Design : Pendekatan Kuantitatif, dan Mixed. Yogyakarta: Pustaka Pelajar, 2010.

[15] Sugiono, Metode Penelitian Pendidikan. Bandung: Alfabeta, 2009.

[16] D. R. E. Cotton, "Implementing curriculum guidance on environmental education: The importance of teachers' beliefs," J. Curric. Stud., vol. 38, no. 1, pp. 67-83, 2006, doi: $10.1080 / 00220270500038644$.

[17] A. Chatzifotiou, "Environmental education, national curriculum and primary school teachers. Findings of a research study in England and possible implications upon education for sustainable development," Curric. J., vol. 17, no. 4, pp. 367-381, 2006, doi: 10.1080/09585170601072478.

[18] J. B. De Pauw and P. Van Petegem, "The effect of eco-schools on childrens environmental values and behaviour," J. Biol. Educ., vol. 47, no. 2, pp. 96-103, 2013, doi: 10.1080/00219266.2013.764342.

[19] N. Hariyati and A. H. Namat, "Environment-Based Curriculum Management In Primary School," vol. 118, pp. 3912-3915, 2017, doi: 10.2991/icset-17.2017.110.

[20] D. Gan, A. Gal, R. Könczey, and A. Varga, "Do eco-schools really help implementation of ESD?: A comparison between eco-school systems of Hungary and Israel," Hungarian Educ. Res. J., vol. 9, no. 4, pp. 628-653, 2020, doi: 10.1556/063.9.2019.4.53.

[21] B. Prabawani, I. M. Hanika, A. Pradhanawati, and A. Budiatmo, "Primary schools eco-friendly education in the frame of education for sustainable development," Int. J. Environ. Sci. Educ., vol. 12, no. 4, pp. 607-616, 2017. 